\title{
NUTRITIVE VALUE AND ENSUING CHARACTERISTICS OF GUATEMALA GRASS HARVESTED AT DIFFERENT STAGES OF MATURTYY
}

\author{
A.N.F.PERERA and E.R.K.PERERA \\ Department of Animal Science, Faculty of Agriculture, University of Peradeniya, \\ Peradeniya.
}

(Received : 21 February 1994; accepted: 12 August 1994)

\begin{abstract}
Guatemala grass (Tripsacum laxum. Nash.) was cultivated in the mid country region with fertilizer application. Fodder was harvested using three cutting intervals at 8,10 and 12 weeks. Ensiling was done with chopped fodder in plastic laboratory silos and initial samples taken to determine the nutritive value. Silos were open after 12 weeks of ensiling. Dry matter, neutral detergent fibre, acid detergent fibre and water soluble carbohydrates significantly increased $(p<0.05)$ with maturity. No significant changes were observed in hemicellulose, cellulose and acid detergent lignin ( $\mathrm{ADL}$ ). On opening the silos, all silages exhibited acceptable physical characteristics. Crude protein was high even at late maturity. The $\mathrm{pH}$, water soluble carbohydrates and in vitro dry matter digestibilities were not significantly changed. Lactic acid and acetic acid were not affected but propionic acid was reduced $(p<0.05)$ with maturity.
\end{abstract}

Key words: Ensiling characters, fodder, Guatemala grass, nutritive values, silages.

\section{INTRODUCTION}

Guatemala grass (Tripsacum laxum. Nash) was introduced to Sri Lanka from Central America. At present it is extensively used in tea plantations as a soil conditioner. However, its fodder value has been recognized in many other countries. In Kenya and Burundi, one of the major sources of feed for dairy cattle is Guatemala grass. ${ }^{1}$ Locally, the feeding potential of this grass has not been carefully investigated. At high altitudes $(>1000 \mathrm{~m}$ ) where the grass grows well, it is not properly utilized as fodder due to restrictions imposed by the plantation management on harvesting.

Guatemala grass can withstand moderate water logging conditions and mild dry spells. These characteristics are important in areas where other pasture and fodder species cannot be grown due to unfavorable soil conditions. Guatemala grass also yields a high biomass area with a substantial dry matter content. ${ }^{2}$ When mixed with Kikuyu grass in up country areas it can overcome problems associated with low dry matter in Kikuyu grass. Studies in other countries revealed that Guatemala grass is excellent fodder for milk production. ${ }^{3}$ No harmful substances have yet been detected in Guatemala grass.

\section{METHODS AND MATERIALS}

Guatemala grass was grown at Peradeniya, on alluvial soil, with a soil pH of 6.7. The grass was established in September 1991, by stem cuttings in $4 \times 4 \mathrm{~m}$ plots with four replications, arranged in a randomized block design. $\mathrm{N}, \mathrm{P}$ and $\mathrm{K}$ were applied at the rate of 150,120 and $100 \mathrm{~kg} / \mathrm{ha}$ respectively, as basal dressing 
recommended for fodder grasses in the mid country. ${ }^{4}$ After one year of establishment, according to a pre-planned schedule, all the plots were harvested on the same day for ensiling. As treatments 8,10 and 12 wks growth stages were taken. The forage was harvested $20 \mathrm{~cm}$ above ground level and chopped to a length of $2-3 \mathrm{~cm}$. The chopped forage was allowed to wilt in shade for about $5 \mathrm{~h}$ prior to ensiling.

Chopped forage samples from each treatment were taken before ensíling and stored at $-20^{\circ} \mathrm{C}$ for subsequent analysis. Four laboratory silos each containing $2.5 \mathrm{~kg}$ were prepared from each treatment. The chopped forage to be ensiled were firmly packed by hand into 31 plastic buckets with a diameter of $24 \mathrm{~cm}$, double lined with polyethylene. The bags were sealed in vacuo.

Laboratory silos were kept at room temperature and opened after 12 wks. After opening, the first few $\mathrm{cm}$ of the silage from the top was discarded before sampling. Physical characteristics such as colour, smell, texture and the presence of moulds were observed. Water extracts of initial and fermented mixtures were prepared. ${ }^{5}$ Filtered water extracts were used for measuring $\mathrm{pH}$; volatile fatty acids (VFA), ${ }^{6}$ lactic acid (LA) ${ }^{7,8}$ and water soluble carbohydrate (WSC). ${ }^{9,10}$

Kjeldahl $\mathrm{N}$ was determined in initial and fermented samples using fresh samples with Kjeltec auto analyzer. Dry matter of both initial and fermented samples were determined by drying about $200 \mathrm{~g}$ of fresh material in an oven at $60^{\circ} \mathrm{C}$, until an uniform weight was obtained. The dried samples were ground in a laboratory mill to pass $2 \mathrm{~mm}$. sieve, and analyzed for dry matter (DM), neutral detergent fibre (NDF), ${ }^{11}$ Acid detergent fibre (ADF), ${ }^{12}$ Acid detergent lignin $(\mathrm{ADL})^{13}$ and in vitro dry matter digestibilities (IVDMD). ${ }^{14}$ The results were analyzed statistically by the analysis of variance. ${ }^{15}$

\section{RESULTS AND DISCUSSION}

Guatemala grass, generally a robust and a fast growing fodder, is low in DM even at $8-10$ wks of age, compared to other fodder species at the same maturity. When the harvesting was delayed from 10 to $12 \mathrm{wks}$, the change in DM was only 15.7 to $18.6 \%$ (Table 1). This indicates a succulent fodder, which improves palatability even at late maturity. In contrast, Guinea grass, which reaches maturity at about 8 wks, has a DM content of about $25 \% .{ }^{16}$ Crude protein (CP) content of Guatemala grass significantly decreased $(p<0.05)$, from 16.3 to $13.3 \%$, when maturity increased from 8 to 12 wks. A similar response was observed in Guinea grass with increasing maturity from 2 to 3 wks. ${ }^{17}$ The results of this study revealed a high CP content of Guatemala grass even at late maturity compared to Guinea grass. Therefore, Guatemala grass can be considered as an excellent fodder for the mid-country and a substitute for Guinea grass which deplete the CP during a short growth period.

Maturity from 8 to 12 wks, increased the NDF and ADF significantly $(p<0.05)$. This is a common phenomenon in plants as they build up their structural material during maturation. However, the values were higher than 
those reported for other fodder grasses. ${ }^{17}$ This may be due to different growing patterns. No significant changes in hemicellulose and cellulose were observed due to maturity in the present study. Similar observations have been made by others, ${ }^{17}$ in another predominant fodder grass, NB 21. ADL was significantly increased $(p<0.05)$, with maturity and these values were comparable to other fodder grasses. ${ }^{3}$

Table 1: Composition, cell wall constituents and water soluble carbohydrates of Guatemala grass harvested at different maturities.

\begin{tabular}{lcccc}
\hline & \multicolumn{3}{c}{ Stage of harvest (wks) } \\
\cline { 2 - 4 } Constituents & 8 & 10 & 12 & SE \\
\hline Dry Matter (\%) & $15.7^{\mathrm{b}}$ & $16.3^{\mathrm{b}}$ & $18.6^{\mathrm{a}}$ & 0.11 \\
Crude Protein (\%) & $16.3^{\mathrm{a}}$ & $15.3^{\mathrm{ab}}$ & $13.3^{\mathrm{b}}$ & 0.57 \\
NDF (\%) & $60.6^{\mathrm{a}}$ & $62.3^{\mathrm{ab}}$ & $65.4^{\mathrm{b}}$ & 0.85 \\
ADF (\%) & $30.4^{\mathrm{a}}$ & $31.8^{\mathrm{ab}}$ & $34.4^{\mathrm{b}}$ & 0.59 \\
Hemicellulose (\%) & 30.2 & 30.5 & 31.3 & 0.97 \\
Cellulose (\%) & 24.0 & 23.2 & 16.5 & 1.46 \\
ADL (\%) & 6.4 & 7.2 & 7.6 & 0.15 \\
WSC (\%) & $9.8^{\mathrm{b}}$ & $11.8^{\mathrm{a}}$ & $12.3^{\mathrm{a}}$ & 0.14 \\
\hline
\end{tabular}

Means followed by the same letter within a row are not significantly different $(p<0.05)$.

WSC content increased ( $p<0.05$ ) with increasing maturity from 8 to 10 wks. However, no significant changes were observed between 10 to 12 wks. WSC was higher in Guatemala grass compared to many other tropical pastures and fodder grasses. This may be due to the characteristic late maturation of this crop and an inherent ability to maintain the quality for long periods. WSC are important in ensiling, since they are the key components responsible for the quality and the preservation of the final product. ${ }^{16}$

On opening the silos, it was found that silages in all treatments were satisfactorily ensiled. Moulds were observed only at the top and this is generally unavoidable in laboratory silos. Aroma, texture and colour compared favourably with previous studies. ${ }^{16}$ The $\mathrm{pH}$ of the silages were not affected by the stage of maturity and they ranged from 4.7 to 5.3. Many experiments suggested that in a well preserved silage, the $\mathrm{pH}$ should be 4.2 or below. ${ }^{18}$ Generally, such $\mathrm{pH}$ is reported in corn silage and silages with high levels of WSC by using additives. In this experiment the Guatemala grass silage was prepared without any, addition of WSC, and hence the $\mathrm{pH}$ could be considered satisfactory. The trend of changes in CP of the initial material was exhibited in the same manner in the silages (Table 2). However, the DM contents slightly increased in silage. This may be due to evaporation caused by the heat generated during fermenta- tion. This observation is in agreement with other fodder grasses such as Guinea grass and NB 21, used in making silage. ${ }^{17}$ 
Table 2: Composition, $\mathrm{pH}$, water soluble carbohydrates and in vitro digestibilities of Guatemala grass silage ensiled at different maturities.

\begin{tabular}{lcccc}
\hline & \multicolumn{3}{c}{ Stage of harvest (wks) } & \\
\cline { 2 - 4 } Constituents & 8 & 10 & 12 & SE \\
\hline Dry Matter (\%) & $15.1^{\mathrm{b}}$ & $18.9^{\mathrm{a}}$ & $20.1^{\mathrm{a}}$ & 0.23 \\
Crude Protein (\%) & $16.0^{\mathrm{a}}$ & $14.9^{\mathrm{ab}}$ & $12.7^{\mathrm{b}}$ & 0.36 \\
pH & 4.7 & 4.8 & 5.3 & 0.03 \\
WSC (\%) & 6.7 & 7.6 & 8.5 & 0.43 \\
IVDMD (\%) : & & & & \\
$\quad$ Grass & 62.1 & 61.7 & 60.8 & 0.76 \\
$\quad$ Silage & 59.9 & 58.6 & 57.9 & 0.89 \\
\hline
\end{tabular}

Means followed by the same letter within a row are not significantly different $(p<0.05)$.

The IVDMD of both initial grass and in silage were not significantly affected by maturity. But IVDMD values of silage were a little lower than in the initial grass. Values for both grass and silage were higher than for many other fodders reported. Generally, in Guinea grass the IVDMD declined sharply with matu. rity. ${ }^{3}$

VFA in the final product gives an estimate for the ensiling characteristics and the quality of the silage.In this study the acetic acid (AA) content ranged from 4.5 to $5.5 \%$, with no significant difference in response to maturity (Table 3 ). The concentration of the AA is in agreement with the silage made with Guinea grass and NB 21. ${ }^{17}$ Propionic acid (PA) significantly decreased, whereas, butyric acid (BA) increased $(p<0.05)$ with maturity. LA ranged from 2.3 to $3.0 \%$. Reduction in PA with maturity was also observed in other fodder grasses such as Guinea grass and NB 21. Although the BA content is expected to be low in silage, it is at a low level in Guatemala grass silage $(0.4$ to $0.7 \%)$ than in guinea grass silage (0.78 to $1.17 \%$ ). In well preserved silage, the BA content has been reported to be less than $0.2 \% .{ }^{18}$ However, in our study the level is three times higher than recommended, but lower than for Guinea grass. The LA content in well preserved silage should be between 3 to $13 \%$ on DM basis. ${ }^{19}$ In the present study, LA was 2.3 to $3.0 \%$. Lactic acid, the predominant acid in silage, determines the preservation characteristics of the final product, which is also dependant on the availability of WSC and the lactogenic organisms present. Many studies have indicated that to maintain the LA level, additions of WSC or cultures of LA fermenting bacteria or both are important during the ensiling process. However, in many tropical grasses and fodders, WSC is limited and efficient lactogenic bacteria in nature are scanty. As a result, a high LA content in tropical silages is rare. The fermentation pathway of tropical forage silages is reported to be different from temperate forage silages. ${ }^{20,21}$ Factors responsible for the preservation of tropical forage silages are complex and not well understood. ${ }^{20,21}$ However, the reports suggest that silage made with tropical grasses 
contained high levels of AA and PA, this rather than LA determined the preservation process. Many workers have observed that the silages made from tropical grasses contained higher AA and PA, than LA. ${ }^{17}$

Table 3: Volatile fatty acid and lactic acid of Guatemala grass silage ensiled at different maturities.

\begin{tabular}{lllll}
\hline & \multicolumn{3}{c}{ Stage of harvest (wks) } \\
\cline { 2 - 4 } Constituents & 8 & 10 & 12 & SE \\
\hline Acetic acid (\%) & 5.5 & 5.1 & 4.5 & 0.08 \\
Propionic acid (\%) & $3.1^{\mathrm{a}}$ & $2.6^{\mathrm{ab}}$ & $2.1^{\mathrm{b}}$ & 0.04 \\
Butyric acid (\%) & $0.4^{\mathrm{b}}$ & $0.7^{\mathrm{a}}$ & $0.5^{\mathrm{b}}$ & 0.002 \\
Lactic acid (\%) & 3.0 & 2.3 & 2.9 & 0.04 \\
\hline
\end{tabular}

Means followed by the same letter within a row are not significantly different $(\mathrm{p}<0.05)$.

The results indicate that Guatemala grass has delayed maturity compared to other tropical fodder grasses, and therefore the quality can be maintained for a prolonged period. Silage made from this grass exhibited satisfactory ensiling characteristics at varying stages of maturity. Therefore, this promising grass which can withstand low $\mathrm{pH}$ and poorly fertile soils, can be used as a valuable source of fodder either as a green feed or as silage to be utilized during leaner periods.

\section{Acknowledgement}

We acknowledge the technical assistance of T. Gallella, A.M.R.B.Atapattu and T.M.I.R. Sahama and support from the SAREC/NARESA Buffalo Research Programme (Grant No. BF-45).

\section{References}

1. Toutain B. (1987). Fodder production prospects in Wallies and Futuna. Revue d'Elvage et de Medecine Veterinaire de Nouvelle Caledonie 10: 37-46.

2. Mozzer O.L. \& Andrade I.F. (1985). Establishment and management of highly productive grasslands. Herbage Abstracts 56 : 194.

3. Perera A.N.F. (1991). Management of cultivated pastures fodders. Proceedings of the seminar on utilization of feed and feed resources (Abst). Coconut Triangle Livestock Development Centre. National Livestock Development Board. Kurunegala, Sri Lanka.

4. Chadhokar P.A. (1980). Recommendation on tropical forage development. UNDP/FAO Tropical Pasture Development Project, National Livestock Development Board, Peradeniya. 
5. Harmon B.N., Fontenot J.P. \&.Webb jr. K.E. (1975). Ensiled broiler litter and corn forage 1. Fermentation characteristics. Journal of Animal Science 40:144-152.

6. Erwin E.S., Marco C.J. \& Emery E.M. (1961). Volatile fatty acid analysis of blood and rumen fluid by gas chromatography. Journal of Dairy Science 44:1768-1776.

7. Barker S.B. \& Summerson W.H. (1941). The colorimetric determination of lactic acid in biological material. Journal of Biological Chemistry 138: 535-540.

8. Pennington R.J. \& Sutherland T.M. (1956). Ketone body production from various substrates by sheep rumen epithelium. Biochemistry Journal 63:353- 358 .

9. Dubois M., Gilles K.A., Hamilton J.K., Rabers P.A. \& Smith F. (1956). Colorimetric determination of sugar related substances. Analytical Chemistry 28: 350-353.

10. Johnson R.R., Balwani T.L., Johnson L.H., McClure K.E. \& Dehority B.A. (1966). Corn plant maturity. II. Effect on in vitro cellulose digestibility and soluble carbohydrate content. Journal of Animal Science 25: 617-623.

11. Van Soest P.J. \& Wine R.H. (1967). The use of detergents in the analysis of fibrous feeds: IV. The determination of plant cell wall constituents. Journal of the Association of Official Analytical Chemists 50: 50-55.

12. Van Soest P.J. (1963). The use of detergents in the analysis of fibrous feeds: II. A rapid method for determination of fibre and lignin. Journal of the Association of Official Analytical Chemists 48: 829-833.

13. Van Soest P.J. \& Wine R.H. (1968). Determination of lignin and cellulose in acid detergent fibre with permanganate. Journal of the Association of Official Analytical Chemists 51:780-789.

14. Tilley J.M.A. \& Terry R.A. (1963). A two stage technique for the in vitro digestion of forage crops. Journal of British Grassland Society 18: 104-111.

15. Statistical analysis systems (1982). Statistical Analysis System, User's Guide: Statistics, Statistical Analysis Systems Institute Inc. Cary, NC, USA.

16. Perera A.N.F. \& Madawala N.K. (1990). Fermentation characteristics and quality of mature Guinea grass ensiled with anaerobically digested cattle manure. Sri Lanka Journal of Agricultural Science 27: 14-21.

17. Panditharatne S., Allen V.G., Fontenot J.P. \& Jayasuriya M.C.N. (1986). Ensiling characteristics of tropical grasses as influenced by stage of growth, additives and chopping length. Journal of Animal Science 63: 197-207. 
18. Carpintero M.C., Holding A.J. \& McDonald P. (1969). Fermentation studies on lucerne. Journal of Science of Food and Agriculture 20: 677-684.

19. Langston C.W., Irvin H., Gordon C.H., Bouma C., Wiseman H.G., Melin C.G., Moore L.A. \& McCalmant J.R. (1958). Microbiology and chemistry of grass silage. US Department of Agriculture Technical Bulletin. 1187.

20. Catchpoole W.R. \& Hanzell E.F. (1971). Silage and silage making from tropical forage species. Herbage Abstracts 41: 213.

21. Aguilera G.R. (1975). Dynamics of the fermentation of the tropical silage. 1. Elephant grass (P. purpurium) without additives. Cuban Journal of Agricultural Sciences 9(2):227-233. 